\title{
3. THE WAY ANIMATION THEATRE IS PERCEIVED AT DIFFERENT AGES
}

Andreea-Corina Ionescu ${ }^{183}$

\begin{abstract}
The game for the child represents everything - develops and stimulates communication, senses, mediates emotional states, solves certain conflict situations. Most of the time, the child uses toys as substitutes for real beings, engaging them in daily activities such as eating, sleeping, walking in the park. For a child there are no barriers between what is real and what is fiction, so when he sees on stage a doll that has life, he will walk with you in the story, whether he likes that story or not. They trust the messages that the stories offer, given the animist view of everyday life. Besides, their behavior demonstrates it - they shout, they grieve, they are frightened, they enjoy every moment with the heroes of the stories that perform in front of them, living with intensity everything that happens.
\end{abstract}

Key words: animation theater, emotion, puppet, story, children, art, game, fairytale

\section{Introduction}

The animation theater is the child's first contact with art, an experience he will surely remember fondly. Also, this place may be the only one where he takes direct contact with the world of stories, not being directed by the technology that takes over our daily lives. For some children, this can be an incentive to enter later on in the boundless world of reading, of books. The values he receives - truth, justice, fairness, respect - when he watches a show are fundamental to its own perfection. I'm not saying that these values can't be acquired any other way, but the way of transmission and assimilation in an animation theater show is much easier. The dramaturgy for animation theater is based on this sensitive layer of moral education, exemplifying behavioral patterns often encountered. The heroes in the stories are often the heroes of children's games. The desire to be someone else or something else is what pursues both the child and the adult, throughout life. Few are reconciled to their own condition. Without imagination, our lives would be deserted. In fact, everything that surrounds us and is created by human hands is the fruit of the imagination, and our behavior is the expression of the image we have created of ourselves.

\section{Discussions}

The imagination fulfills in the child a role of soul balance, resolves the contradiction between the desires and the possibilities of the child. ${ }^{184}$ Most of the time, the imagination starts from what is real, transforming and altering at a mental level what will be achieved concretely through practical thinking and action. An eloquent example is provided by the writer Jules Verne, who anticipated in the

${ }^{183}$ Candidate Doctoral, "Ion Luca Caragiale" National University of Theatrical and Cinematographic Art from Bucharest, Romania, email: andreeacorinaioneascu@gmail.com

184 Dragu, Anca, Cristea, Sorin (2003), Psihologie și pedagogie școlară, Editura Ovidius University Press, Constanța, pg. 43 
nineteenth century the remarkable achievements of science, technic and technology of the twentieth and twenty-first centuries. Today, imagination is not stimulated in terms of education, but if we manage to keep it active from the beginning of the childhood period, imagination becomes the greatest quality a person can have. The purpose of the animation theater is to stimulate the imagination, to free it from the chains imposed by the surrounding reality.

The fiercest enemy of the imagination is the very environment in which we live - family, school, professional activity etc. - which does not create the right premises for development. Beyond concrete reality, however, is a world that becomes possible only through the imagination; Tudor Arghezi wrote Man, crazy man, you make miracles without knowing and you don't know almost nothing about the formidable power of your thinking. Know that everything you imagine is achievable and is done in direct proportion to your confidence ...

The animation theater should be part of everyone's life, considering that this kind of theater, often minimized, is synonymous with the emotion of discovering a special world. A world in which fascination, mirage, contradictory feelings intertwine, and the imagination is boundless; the essential condition for entering this world is the unleashing of the imagination. Also, play and playing are essential conditions for the animation theater to complete its mission.

The game for the child represents everything - develops and stimulates communication, senses, mediates emotional states, solves certain conflict situations. Most of the time, the child uses toys as substitutes for real beings, engaging them in daily activities such as eating, sleeping, walking in the park. For a child there are no barriers between what is real and what is fiction, so when he sees on stage a doll that has life, he will walk with you in the story, whether he likes that story or not. They trust the messages that the stories offer, given the animist view of everyday life. Besides, their behavior demonstrates it - they shout, they grieve, they are frightened, they enjoy every moment with the heroes of the stories that perform in front of them, living with intensity everything that happens.

Piaget emphasized that the game is closely related to the formation of intelligence, this being a means of assimilation and confirmation of what surrounds them, but also having the role of self-defense shield against the overwhelming reality that forces them to adapt.

In their game, children like to disseminate anything until consumption, believing that so they can discover the interior where that object has his soul. It is important for the child to feel and not to understand concretely what he sees in front of him, he can comprehend the meaning of the smallest gesture, even though he didn't passed through the whole story. Puppets stimulate fantasy and bring creative benefits, especially in the first seven years of a child's life. This power that fantasy has over the child comes from the senses, that being the only source of learning and knowledge that the child has until that age.

Jean Chateau emphasized in his work The child and the game that through games, the child manifests his valences and possibilities that can be seen at the surface level of his being, the game world being a precursor to his future concerns, an exercise, in an imaginatively plan, of his future personality. Chateau also wrote 
that $A$ child who does not want to play is a child whose personality does not assert itself, who is content to be small and weak, a human being without pride, a human being without a future. ${ }^{185}$

An animated theater show can offer the child an almost complete sensory experience, especially today, when children are mentally overstimulated by the technology around them. Thus, it gives him rich impulses in feelings that develop the creative imagination and harmoniously perfect his future personality. The child subconsciously transposes the stories he watches on stage, realizing that no matter what obstacles you encounter in life, kindness and honesty will always have a place of honor at the end of the journey, most of the children are identifing them selves with characters with positive qualities.

The school, the family environment and society itself encourage egocentrism and selfishness. The child is, by definition, around the age of seven, an egocentric being, as Piaget demonstrated in his studies, but the puppet theater discourages this type of behavior, bringing to light those stories that encourage altruism and the appreciation of the ones that are arround us, giving him an emotional balance that restores his confidence, even when he feels powerless in the face of the unknown.

\section{Results}

The child's need to be creative comes from his need to express himself. Retreat into an imaginary world is a consequence of the maladaptation and misunderstanding of the world around, this accommodation being achieved through games, not being just a characteristic process of childhood; according to Piaget, this process continues throughout life, through a process of accommodations and re-accommodations, depending on the level of development of the individual from a socio-cultural point of view, but also on the evolution of society itself. In fact, Freud emphasized that each individual suffers not only from the influence of his current civilized environment, but also from that of the environments in which his ancestors lived. ${ }^{186}$ The artistic creation is capitalized only when it was received! As an artistic creation goes through a series of stages, also in the same key the perception of the performance by a child, it is necessary to follow some defining stages, to which I will refer in the following.

The first stage is to prepare the little spectator for coming to the theater. It is important that the story is known and appropriate for the child's age category. The little spectator needs to be emotionally prepared to meet the characters in the show - for some children this can be shocking, especially on the first date. Although they have no problem being carried away by the story and the action, the moment they realize that those characters are living without their help, it can be shocking, the child sometimes refuses to continue watching. I met many times in the performance hall, parents with children under 3 years old, struggling to make them stay on the chair until the end of the show. It is a totally wrong attitude, which can generate in the child's subconscious a generalized fear of theater.

\footnotetext{
${ }^{185}$ Chateau, Jean (1967), Copilul si jocul, Editura Didactica si Pedagogica, Bucuresti, pg.19-34

${ }^{186}$ Freud, Sigmund (1980), Introducere in psihanaliza, Editura Didactica si Pedagogica, Bucuresti, pg. 32 
The second stage is the actual reception. Many creators of children's theater performances resort to interactivity with the public, in order to facilitate the correct transmission of the artistic message. When there is a dialogue with the room, an incredible exchange of energies takes place, and the artistic creation reaches the ideal form through the open and vivid communication of the message.

The third stage is an evaluation. This stage seems fundamental to me, due to the personal character it contains. The discussion about the story and the show can be a bridge between the child and the parent and between the child and the artistic act. There are moments that he may not have understood, but that have remained hanging in his memory and that he needs to clarify; it is also important to consciously summarize everything he saw and felt during the show.

The child is not a smaller man, moreover he is not a man, but a virtuality, a "candidate for humanity" - wrote H. Pieron; the transformation of the child into a human being is achieved in a long educational process under the influence of society - a society meant not to inhibit creativity, but to develop and cultivate it. Unfortunately, as Herbert Read pointed out in his book The Origins of Form in Art, educating creativity, imagination and sensitivity is not a priority in today's society. Neither in school nor later, engaged in the classical systems of work, people are not encouraged to develop feelings and no time is provided for free activities in terms of the arts. The primary purpose of education is knowledge, but not the creation, thus becoming a divided society, neurotic and vengeful, to the detriment of one united by love.

Educating imagination together with sensory education is the basis from which any type of institutionalized education should start. With the help of the imaginary, any child can more easily access the real, and this can be done with the help of the stories we tell. Children have the ability to transpose themselves endlessly and directly into any story, they manage to live with maximum intensity everything that happens in front of them. In terms of their concentration in the activities undertaken, it increases exponentially from 5-7 minutes - 2-3 years -, to 12-14 minutes - 3-4 years - and to 20-25 minutes - 4-5 years -, reaching after the age of 6 years up to 45-50 minutes. It is very important that when making a show for children to be clear in mind for what age category it is intended. Bruno Bettelheim made an analysis from a psychoanalytic perspective regarding the fact that each age category is assigned a certain type of fairy tale, which corresponds to the stage of development of the child and responds to age-specific issues. In the same key, in my doctoral thesis Dramaturgy in the animation theater, I have outlined the type of dramaturgy specific to each age category, as well as some of the aspects that a playwright or a director should take into account when making a animation theater performance. Broadly speaking, in the evolution as a spectator of a child, one must take into account his mode of development, and the way he plays, is defining in this sense.

By the age of 3, the child accumulates and progresses mentally, emotionally and socially, he discovers himself, learning to speak, walk, touch, feel and absorb everything around him, through the five senses they develop. Its game is based on exploration, testing and learning. Performances for this age group should present 
simple themes, without conflict, strong light and sharp or serious sounds; this category includes sensory performances.

At 3 years old, the child is curious and asks many questions, begins to play different roles, the imaginary friend appears with whom he walks in many adventures. At this age he begins to differentiate between positive and negative characters, but he participates with some fear in the show, not having enough patience to watch the show from the beginning, unless the story or image he sees keeps him captive.

Between 4 and 5 years old, he is able (if he received his education in this sense) to watch a show from head to tail, without being disturbed by the external noises that break through the performance hall. Also, he will live with obvious emotion everything that happens in front of him, managing to distinguish between real and imaginary. During this period, if the story does not fall within his area of interest, the child will fight back, and will even do everything possible to sabotage the show - the parent is directly responsible for its preparation before the show, but also for the evaluation after.

Shows between 3 and 6 years old should be dynamic, with simple actions, bright and engaging, easily interactive, without dramatic exaggerations and without strong conflicts. Stories with animal characters are quite suitable for this category.

Between 6 and 7 years, the critical spirit and a certain skepticism intervene. The child at this age is interested in the way the character is animated, from what it was made and how the respective effect was achieved, in order to unmask the respective trick. Children are attracted to fantastic stories, to those they have studied or read.

Between 9 and 10 years old, due to infant maturity, children easily refuse the fantastic, so it rarely happens to come to the animation theater, being considered in the social groups to which they belong an activity for the little ones, they no longer have the availability to be teleported in the story played by the actors. The shows suitable for this age category are those that deal with certain age-specific characteristics or issues, myths, legends or even works from classical literature.

\section{Conclusions}

Stories told or represented correctly from a psychological point of view can open unsuspected doors in the child's subconscious, which will be reflected later in the choices that the adult will make. They can generate answers for his worries and behavior patterns for adaptation to social life. Bruno Bettelheim pointed out that Regardless of age, only a story in accordance with the principles that underpin our thought process is convincing to $u s^{187}$. What technology is not capable of doing, but an animation theater performance can certainly succeed, is to allow the child to develop that emotional side so minimized today. Our role as creators is important, but beyond that is that of the parent who accompanies the little spectator on his journey to the magical world of puppets and stories.

${ }^{187}$ Bettelheim, Bruno (2017), Psihanaliza basmelor, Editura Univers, București, p. 69. 


\section{References}

1. BEJAT, Marian (1971), Editura Stiintifica, colectia Psyche, Bucuresti

2. BETTELHEIM, Bruno (2017), Psihanaliza basmelor, Editura Univers, Bucuresti

3. DRAGU, Anca, CRISTEA, Sorin (2003), Psihologie și pedagogie școlară, Editura Ovidius University Press, Constanța

4. PIAGET, Jean (1965), Psihologia inteligenţei, Editura Ştiinţifică, Bucureşti

5. READ, Herbert (1971), Originile formei in arta, Editura Univers, Bucuresti

6. SHAMS-ZANDJANI, Margaret M. (2002), An examination of children's senses, the damaging effect of the media and the therapeutic possibilities of puppetry, Easter, Rome 